\title{
CORRIGENDUM
}

\section{Usefulness of direct fluorescent in buffy coat in the diagnosis of Candida sepsis in neonates}

MA Higareda-Almaraz, H Loza-Barajas, JG Maldonado-González, E Higareda-Almaraz, V Benites-Godínez and E Murillo-Zamora

Journal of Perinatology (2016) 36, 912; doi:10.1038/jp.2016.129

Correction to: Journal of Perinatology advance online publication, 16 June 2016; doi:10.1038/jp.2016.96
The fifth author's name was presented incorrectly. Their name should appear as V Benítes-Godínez. 